\title{
European Certificate of Primatology
}

Announcement of 2000 Course

The European Federation for Primatology (EFP) and the German Primate Center (DPZ) announce the 2000 European Certificate of Primatology (ECP). The ECP is a scientific activity of the European Federation for Primatology. It is organised in cooperation with universities or scientific institutions within the European Community on a rotating basis. The 2000 course will be held in Göttingen, Germany, and will be organised by the German Primate Centre. This course will provide students with a sound knowledge in primatology, addressing basic topics as well as exploring new developments.

The ECP is targeted at students of biology, medicine and veterinary medicine. Students from other disciplines (e.g. psychology) may also participate, provided they meet the requirements for admission. If the number of participants permits, professionals from medical and veterinary medical sciences who wish to obtain a deeper knowledge in primatology may also participate.

Date and Location

The course will be held for 3 weeks from March 13-31, 2000, at the German Primate Centre (DPZ) in Göttingen, Germany.

Content and Topics of the ECP

The following topics will be included in the ECP course:

- Diversity, taxonomy and phylogeny of primates

- Comparative and functional morphology

- Genetics

- Ecology

- Behavioural ecology

- Cognition

- Virology and Immunology

- Parasitology

- Pathology

- Reproductive physiology

- Captive management

- Conservation biology

- Ethics of experimental research

Components of the ECP

The ECP course includes the following components:

- Lectures and seminars of 2-4 hours duration

- Practical demonstrations

- Excursions to institutions holding primates

\begin{tabular}{ll}
\hline KARGER & ( 1999 S. Karger AG, Basel \\
Fax + 41613061234 & \\
$\begin{array}{l}\text { E-Mail karger@karger.ch } \\
\text { www.karger.com }\end{array}$ & $\begin{array}{l}\text { Accessible online at: } \\
\text { www.karger.com/journals/fpr }\end{array}$
\end{tabular}


Requirements for Admission and Number of Participants

To participate in the ECP course, students must have finished the basic studies in their respective disciplines. They should hold the Vordiplom, BSc or an equivalent degree in biology. Alternatively they may have completed at least two years of study in medicine or veterinary medicine. For students from other disciplines, a first degree or at least two years of study are a precondition.

The number of participants is limited to 20 , and the course will not be run with less than 12 participants.

Lecturers

Lectures will be held by experts from European countries in different fields of primatology.

Language

All courses will be held in English.

\section{Certification}

To obtain a certificate, participants must provide a written report on the course within 3 months of its end. These reports will be evaluated by the organisers of the ECP.

Fees

The fee for students is 150 Euro. This includes housing during the course. The fee for persons in employment is 300 Euro.

Application

To apply for participation, students should send a letter to:

ECP2000

Dr. Eckhard W. Heymann

Deutsches Primatenzentrum

Kellnerweg 4

D-37077 Göttingen (Germany)

Letters must be accompanied by relevant certifications showing that the requirements for admission are met. If available, an e-mail address should be provided for rapid communication. Applications will be dealt with in order of receipt. Applicants will be informed of the outcome as soon as possible.

Deadline for application: December 15, 1999.

Further information can be obtained at ECP2000@www.dpz.gwdg.de

Dr. Paul Winkler

Centre for Tropical and Subtropical Agriculture and Forestry (CeTSAF)

Am Vogelsang 6

D-37075 Göttingen (Germany) 